\title{
Krzywda i jej zadośćuczynienie w prawie cywilnym. Analiza pojęć w świetle orzecznictwa sądów polskich
}

\section{Uwagi wprowadzające}

\} \text { starożytności wyrządzenie drugiemu człowiekowi szkody niemajątkowej } sób ochrony dóbr majątkowych i niemajątkowych regulowany poprzez normy moralne i obyczajowe. Sankcją za uszkodzenie zdrowia lub śmierć osoby była kara talionu (odwet). W prawie rzymskim prawnicy posługiwali się pojęciem Iniuria rozumianym jako bezprawne naruszenia osobowości człowieka wolnego, dotyczyło ono m. in takich elementów tożsamości człowieka jak jego ciało (corpus), godność (dignitas) i dobre imię (fama) ${ }^{1}$. Przepisy prawa rzymskiego wprowadziły możliwość zastąpienia zemsty okupem, który to stanowił dobrowolne zrzeczenie się przez poszkodowanego zemsty w zamian za wypłacenie mu sumy pieniężnej. Wprowadzona w Cesartwie Rzymskim lex Cornelia de iniuriis przewidywała obok kar prywatnych także odpowiedzialność karną za ciężkie przypadki naruszenia nietykalności cielesnej². W europejskich regulacjach prawnych rozwiązania wypracowane przez prawo rzymskie funkcjonowały do końca XVIII w.

W epoce oświecenia przedmiotem dyskusji naukowej stało się zagadnienie dopuszczalności zasądzania kwoty pieniężnej na rzecz poszkodowanego w przypadku, w którym nie dochodzi do powstania materialnego uszczerbku w jego dobrach (np. jako rekompensata za zniewagę lub zgwałcenie kobiety). „W XVIII

\footnotetext{
* Mgr Artur Klimkiewicz - radca prawny; e-mail: arturklimkiewicz@gmail.com.

${ }^{1}$ Por. K. Kolańczyk, Prawo rzymskie, Warszawa 1976 s. 435.

${ }^{2}$ Por. J. Matys, Model zadośćuczynienia pieniężnego z tytułu szkody niemajątkowej w kodeksie cywilnym, Warszawa 2012, s. 28 i n.
} 
w. istotnym stało się zagadnienie słuszności zasądzania kwoty pieniężnej na rzecz poszkodowanego w przypadku, w którym nie dochodzi do powstania materialnego uszczerbku. Rozważania te były obecne od początku pojawienia się opisywanej instytucji, jednak dopiero w tym czasie ostatecznie przychylono się do stanowiska, iż za właściwą i wystarczającą uznać należy odpowiedzialność karną" "Zwracano uwagę, że regulacja prawna wypracowana w prawie rzymskim miała charakter represyjny polegający na wyrządzeniu dolegliwości sprawcy czynu i represji czyli odstraszaniu innych od czynienia w podobny sposób. Pod wpływem nowych nurtów filozoficznych jako pierwszoplanową zaczęto wskazywać funkcję kompensacyjną zadośćuczynienia, której istotą było przywrócenie równowagi zburzonej wyrządzonym czynem po między sprawcą a pokrzywdzonym. Ta koncepcja zgodnie, z którą pokrzywdzony uzyskujący świadczenie od sprawcy powinien jedynie zrekompensować doznany uszczerbek a nie wzbogacić się na swej krzywdzie jest jedną z fundamentalnych zasad współczesnego prawa polskiego. Można twierdzić więc, że cywilnoprawna sankcja prawna, która pojawia się w związku z wyrządzeniem krzywdy drugiej osobie w prawie polskim pozbawiona jest elementów represyjnych.

\section{Zadośćuczynienie za cierpienia fizyczne i krzywdę moralną w świetle regulacji Kodeksu zobowiązań}

Kształtowanie się nowoczesnego prawa polskiego w okresie dwudziestolecia międzywojennego związane było silnie z wpływami regulacji prawnych państw zaborczych w których omawiana kwestia regulowana była w różny sposób. Dla przykładu obowiązujący na ziemiach polskich zaboru austriackiego Codex Teresianus a potem $A B G B$ zadośćuczynienie ujmowały jako karę prywatną. ABGB ( $\$ 1325$ i $\$ 1331$ ) stanowiły, że naprawienia szkody niemajątkowej od sprawcy szkody można było się domagać w przypadku uszkodzenia ciała, jako nawiązki za doznany ból oraz jako wartości szczególnego upodobania tzw. pretium affectionis.

Twórcy polskiego Kodeksu zobowiązań przyjęli założenia filozoficzne szkoły prawa natury i wprowadzili rozwiązania umożliwiające majątkową rekompensatę za doznane cierpienia fizyczne lub psychiczne. Idąc za wzorem niemieckiego BGB ustawodawca w okresie dwudziestolecia międzywojennego uznał, że zadośćuczynienie pieniężnie za szkodę niemajątkową może być przyznane jedynie w ściśle określonych sytuacjach. Polska regulacja prawna prócz zadośćuczynienia pieniężnego za cierpienia fizyczne i krzywdę moralną z art. 165 i 166 k.z. na podstawie art. 160 k.z. dawała podstawy do domagania się odszkodowania za

${ }^{3}$ I. Lewandowska-Malec, Dobra osobiste, Warszawa 2014, s. 11 por. cytowane tam piśmiennictwo. 
zniszczenie rzeczy szczególnego upodobania (pretium affectionis) ${ }^{4}$. Art. $165 \$ 1$ k.z. stanowił, że „W razie uszkodzenia ciała lub wywołania rozstroju zdrowia, pozbawienia życia, pozbawienia wolności lub obrazy czci, sąd może przyznać poszkodowanemu lub instytucji przezeń wskazanej stosowną sumę pieniężną, jako zadośćuczynienie za cierpienia fizyczne i krzywdę moralną. Paragraf 2 stanowił, że przepis powyższy stosuje się również w przypadkach, gdy kobietę albo małoletniego lub psychicznie upośledzonego mężczyznę skłoniono za pomocą podstępu, gwałtu, nadużycia stosunku zależności lub wyzyskania krytycznego położenia do poddania się czynowi nierządnemu. Art. 166 k.z. stwierdzał, że w razie śmierci poszkodowanego wskutek uszkodzenia ciała lub wywołania rozstroju zdrowia, sąd może przyznać najbliższym członkom rodziny zmarłego lub instytucji, przez nich wskazanej, stosowną sumę pieniężną, jako zadośćuczynienie za doznaną przez nich krzywdę moralną. Polska doktryna prawa tego okresu nie posługiwała się jeszcze pojęciem dobra osobistego. $\mathrm{Z}$ tego względu art. 166 k.z., podobnie zresztą jak obecnie obowiązujący art. $446 \S 4$ kodeksu cywilnego ${ }^{5}$, dawał możliwość dochodzenia roszczeń jedynie w przypadkach wyraźnie w nim opisanych. W piśmiennictwie stwierdzano, że celem tej regulacji było zrekompensowanie bólu i cierpienia powstającego w przypadkach wskazanych w treści przepisu. Warto dodać tu, że art. 160 stwierdzał, że przy określaniu szkody majątkowej bierze się pod uwagę wartość rzeczy według cen rynkowych, a w razie złego zamiaru lub rażącego niedbalstwa zobowiązanego do odszkodowania, także szczególną wartość rzeczy dla poszkodowanego. Kwestia ta była komentowana przez przedstawicieli doktryny prawa jako możliwość dochodzenia satysfakcji z tytułu ujemnych doznań psychicznych związanych ze zniszczeniem rzeczy.

Przedstawione uregulowanie prawne zawarte w kodeksie zobowiązań dawały podstawy do twierdzeń że roszczenia przysługują w dwóch odrębnych przypadkach za „cierpienia fizyczne i krzywdę moralną”. Część przedstawicieli doktryny prawa nie zgadzała się z takim ujęciem i krytykowała sens odróżniania obu pojęć. W konsekwencji w orzecznictwie sądowym aprobatę uzyskał pogląd zgodnie z którym cierpienia fizyczne uznaje się za element krzywdy moralnej. Przed wejściem w życie obecnie obowiązującego Kodeksu cywilnego uznawano więc, że suma pieniężna zasądzana tytułem zadośćuczynienia nie może być

${ }^{4}$ Por. A. Śmieja, Instytucja zadośćuczynienia pieniężnego za doznaną krzywdę w kodeksie zobowiązań i w kodeksie cywilnym, Acta Universitatis Wratislaviensis 2009, nr 3161, s. 497 i n.; por. także Z. Radwański, Zadośćuczynienie pieniężne za szkodę niemajątkową. Rozwój i funkcja społeczna, Poznań 1956; S. Grzybowski, Ochrona dóbr osobistych według przepisów ogólnych prawa cywilnego, Warszawa 1957, s. 45.

${ }^{5}$ Ustawa z dnia 23 kwietnia 1964 r. - Kodeks cywilny (tekst jedn. z 2017 r. Dz. U. poz. 682 z późn. $\mathrm{zm}$.) 
przyznawana odrębnie z tytułu krzywdy moralnej, a odrębnie za cierpienia fizyczne ${ }^{6}$.

\section{Krzywda jako konsekwencja naruszenia dóbr osobistych}

W aktualnym stanie prawnym pojęcie zadośćuczynienia za krzywdę pojawia się przede wszystkim w związku z odpowiedzialnością za naruszenie dóbr osobistych. Powszechność ochrony dóbr osobistych sprawia, że ich ochronę prawną wyprowadzić można z przepisów obecnie obowiązującej Konstytucji RP z dnia 2 Kwietnia 1997 r. (Dz. U. Nr 78 poz. 483 z późn. zm.) oraz szeregu ratyfikowanych przez Polskę umów międzynarodowych jak np. Europejska Konwencja o Ochronie Praw Człowieka i Podstawowych Wolności z dnia 4 listopada 1950 r. (Dz. U. 1993 r., nr 61, poz. 284 z późn. zm.). Ochrony dóbr osobistych w prawie polskim poszukiwać można zarówno na gruncie kodeksu cywilnego (art. $24 \$ 1$ i 2 k.c., art. 446 k.c., art. 448 k.c. ), jak i przepisów innych ustaw np., Kodeksu karnego, który chroni życie, zdrowie, cześć ludzką, wolność seksualną itp. Wydanie skazującego wyroku karnego za czyn naruszający cudze dobro osobiste ( np. zdrowie) co do zasady nie wyłącza możliwości dochodzenia roszczeń w procesie cywilnym.

W praktyce najczęstszą podstawą dochodzenia roszczeń z tytułu naruszenia dóbr osobistych (odszkodowania i zadośćuczynienia) są wymienione wyżej przepisy Kodeksu cywilnego. Cywilnoprawna ochrona dóbr osobistych nie ogranicza się jedynie do regulacji Kodeksu cywilnego, obejmuje bowiem także inne środki uregulowane $\mathrm{w}$ innych ustawach o charakterze cywilnoprawnym np. w ustawie z dnia 22 maja 2003 r. o ubezpieczeniach obowiązowych, Ubezpieczeniowym Funduszu Gwarancyjnym i Polskim Biurze Ubezpieczycieli Komunikacyjnych.

Żaden $\mathrm{z}$ aktów prawnych nie zawiera jednak normatywnej definicji pojęcia dobra osobistego. W treści art. 23 k.c. znajdujemy jedynie przykładowe wyliczenie podlegających ochronie dóbr osobistych, którymi są: „zdrowie, wolność, cześć, swoboda sumienia, nazwisko lub pseudonim, wizerunek, tajemnica korespondencji, nietykalność mieszkania, twórczość naukowa, artystyczna, wynalazcza i racjonalizatorska". Wymieniony w treści cytowanego przepisu katalog dóbr osobistych nie ma charakteru zamkniętego, ochrona kreowana przez przepisy prawa cywilnego nie wyłącza ochrony prawnej przewidzianej w innych gałęziach prawa. Dobra osobiste przysługują osobom fizycznym, osobom prawnym i jednostkom, o których mowa w art. $33^{1}$ k.c.

${ }^{6}$ Por. A. Miączyński, Zadośćuczynienie pieniężne za krzywdę spowodowaną naruszeniem dobra osobistego. Geneza charakterystyka i ocena obowiązującej regulacji w: Odpowiedzialność cywilna. Księga pamiątkowa ku czci Profesora Adama Szpunara. Zakamycze 2004, s. 235 i n.; I. Lewandowska-Malec, Dobra osobiste, Warszawa 2014, s. 11. 
Co do zasady dobra osobiste są niemajątkowymi wartościami, które człowiek posiada od chwili narodzin. Zgodnie z zasadą nasciturus pro iam nato habetur quotiens de commodis eius agitur tam, gdzie służy to interesowi nasciturusa, przysługuje mu ochrona analogiczna do tej, którą uzyska po urodzeniu. Po urodzeniu, dziecko może dochodzić roszczeń wynikłych z naruszenia dóbr osobistych, które nastąpiło przed narodzeniem (art. $446^{1}$ k.c.). Cechą dóbr osobistych jest ich ścisły związek z podmiotem (osobą fizyczną lub prawną), której przysługują.

Zgodnie $\mathrm{z}$ dominującym poglądem na gruncie polskiego prawa cywilnego ochrona dóbr osobistych realizowana jest poprzez konstrukcję praw podmiotowych odpowiadających poszczególnym dobrom osobistym. Jak twierdził S. Grzybowski ${ }^{7} z^{2}$ ródeł różnych koncepcji ochrony dóbr osobistych należy szukać, w dziewiętnastowiecznych ustawach. Wzorem ochrony krzywdy moralnej zdaniem tego autora była pochodząca z prawa rzymskiego actiones iniunarium aestimatoriae. Źródło konstrukcji prawa podmiotowego osobistego autor upatruje w doktrynie niemieckiej.

S. Grzybowski istotę prawa podmiotowego określał jako przyznaną podmiotowi stosunku prawnego przez normę prawną sferę prawną możności postępowania, z którą sprzężony jest obowiązek nienaruszania tej sfery przez inne osoby ${ }^{8}$ Wśród różnych typów praw podmiotowych wskazany autor wyróżnił $\mathrm{m}$. in. prawa osobiste, które uważał za prawa o charakterze bezwzględnym, niemajątkowym i nieprzenoszalnym, służące do ochrony ściśle osobistych interesów i stosunków podmiotu prawa. Z. Radwański prawo podmiotowe zdefiniował jako sytuację prawną wyznaczoną podmiotom przez obowiązujące normy, chroniące ich prawnie uznane interesy. Składają się na nią zachowania podmiotu uprawnionego i sprzężone $\mathrm{z}$ nimi obowiązki innego podmiotu lub podmiotów, zagwarantowane przymusem państwowym ${ }^{9}$. Zasadność oparcia ochrony dóbr osobistych na konstrukcji prawa podmiotowego zakwestionował B. Gawlik ${ }^{10}$ Zdaniem B. Gawlika alternatywą dla koncepcji praw podmiotowych osobistych jest instytucjonalna ochrona dóbr osobistych polegająca na tym, że ochrona dóbr osobistych realizowana jest „przez ustanowienie norm postępowania, regulujących konflikty wartości i interesów we wzajemnych oddziaływaniach społecznych"11. W świetle powyższej koncepcji ochrona dóbr osobistych jest więc realizowana przez wprowadzenie odpowiednich nakazów

7 S. Grzybowski, Prawa osobistości ze szczególnym uwzględnieniem przepisów prawa cywilnego i administracyjnego o imieniu i nazwisku, Warszawa 1937, s. 3-4.

8 S. Grzybowski, Prawo cywilne. Zarys części ogólnej, Warszawa 1985, s. 110.

${ }^{9}$ Z. Radwański, Prawo cywilne - część ogólna, Warszawa 1999, s. 88

${ }^{10}$ Gawlik B., Ochrona dóbr osobistych. Sens i nonsens koncepcji tzw. praw podmiotowych osobistych, ZNUJ PWiOWI 1985, z. 41, s. 123-141

11 B. Gawlik, Ochrona dóbr..., s. 123-141 
i zakazów prawnych. O bezprawności nie rozstrzyga więc naruszenie określonego dobra osobistego, ale samo zachowanie sprzeczne z normą postępowania.

W świetle przywołanych wyżej poglądów krzywda będąca konsekwencją naruszenia któregoś z dóbr osobistych jawi się jako konsekwencja ingerencji w sferę zakreślonego przez ustawodawcę prawa podmiotowego.

\section{Krzywda osób trzecich wynikająca z uszczerbku którego doznał poszkodowany jako pojęcie relewantne prawnie}

W sytuacji spowodowania szkody wyrządzonej czynem niedozwolonym obowiązek naprawienia szkody obejmuje wszelkie szkody na osobie i mieniu. Szkodą na osobie jest m. in. śmierć, uszkodzenie ciała, rozstrój zdrowia , krzywda moralna oraz cierpienia psychiczne. Szkoda ta ma swój aspekt majątkowy oraz niemajątkowy. Do sfery majątkowej zaliczają się m. in. koszty leczenia, utrata zarobków, zmniejszenie widoków powodzenia na przyszłość itp. Charakter niemajątkowy ma zaś krzywda, która może być opisywana na wiele różnych sposobów jako ból i cierpienie fizyczne lub psychiczne, obniżony nastrój psychiczny, przygnębienie, utrata radości, życia, rozstrój emocjonalny. Na gruncie prawa polskiego odszkodowanie za szkodę powinno zmierzać do wyrównania różnicy pomiędzy stanem majątkowych przed i po zdarzeniu oraz zniwelowania wszelkich negatywnych konsekwencji które na skutek deliktu powstały w sferze niemajątkowej (tzw. zasada pełnej kompensacji).

Pojęcie krzywdy (oraz zadośćuczynienia za nią) w prawie polskim odnosi się do stanu osoby, która doznała naruszenia oraz do stanu osoby bliskiej ofiary naruszenia. W Polsce podobnie zresztą jak w innych kontynentalnych porządkach prawnych szkodę wynikająca ze śmierci osoby bliskiej rozpatruje się jako naruszenie własnej sfery majątkowej i nie majątkowej osoby trzeciej (osoby bliskiej zmarłego). Podobnie, istotne naruszenie stanu zdrowia osoby np. dziecka może być rozpatrywane jako krzywda osób trzecich np. jego rodziców, wynikająca $\mathrm{z}$ faktu naruszenia dobra osobistego w postaci więzów rodzinnych.

Odnosząc się do kwestii krzywdy wywołanej śmiercią osoby trzeciej w piśmiennictwie dokonano wyodrębnienia dwóch grup systemów prawnych, pierwszego w którym domaga się dowodu poważnego wstrząsu psychicznego spowodowanego śmiercią osoby bliskiej (Niemcy, Austria, Holandia, Szwecja) oraz systemów w których wystarczy wykazanie uczucia żałoby, smutku lub osamotnienia (Szwajcaria, Wielka Brytania, oraz Polska od 2008 r. $)^{12}$.

${ }_{12}$ Por. E. Bagińska, Roszczenie o zadośćuczynienie na podstawie art. $446 \$ 4$ kodeksu cywilnego na tle doświadczeń europejskich w: Kompensacja szkód komunikacyjnych. Nowoczesne rozwiązania ubezpieczeniowe, red. K. Ludwichowska, Warszawa 2011, s. 150-151. 
W odniesieniu do możliwości przyznania zadośćuczynienia za śmierć osoby najbliższej orzecznictwo sądowe jest zgodne co do tego że jest to dopuszczalne zarówno w oparciu o art. $446 \$ 4$ k.c., jak też na podstawie art. 24 k.c. w zw. $\mathrm{z}$ art. 448 k.c. Jak wskazał Sąd Apelacyjny we Wrocławiu „Zadośćuczynienie przyznawane na podstawie art. 23 k.c. i art. 24 k.c. w zw. z art. 448 k.c. ma kompensować nie tyle doznany ból spowodowany śmiercią osoby bliskiej, lecz przedwczesną utratę członka rodziny. Dobrem osobistym, którego naruszenie wymaga rekompensaty, jest prawo do życia w rodzinie”.

Zagadnieniem, które budzi wątpliwości i rozbieżności w polskim orzecznictwie sądowym jest to czy można mówić o naruszeniu dobra osobistego rodziców w postaci „więzi rodzinnej” w sytuacji w której nie dochodzi do śmierci dziecka lecz istotnego pogorszenia jego stanu zdrowia (wywołania jego kalectwa). Problem wywołuje tu kwestia czy uszczerbek na zdrowiu pokrzywdzonego może prowadzić do stwierdzenia wywołanej tym faktem krzywdy osób jej najbliższych.

Sytuacje w których nie dochodzi do śmierci członka rodziny lecz do jego kalectwa są różnie oceniane przez sądy. Oto przykłady tego rodzaju rozstrzygnięć wraz z ich uzasadnieniem. W uzasadnieniu do wyroku Sądu Apelacyjnego w Warszawie z dnia 18 stycznia 2016 r. VI ACa 1405/14, stwierdzono, że rodzice upośledzonego dziecka, które na skutek winy lekarzy przy porodzie doznało ciężkiego uszkodzenia ciała o skutkach trwałych i nieodwracalnych, mogą żądać zadośćuczynienia za wyrządzoną im krzywdę. Naruszone zostało bowiem ich prawo do niezakłóconego życia w pełnej rodzinie, mimo że więzy rodzinne faktycznie nie zostały zerwane.

W podobnym kierunku zmierza orzeczenie SN z dnia 9 sierpnia 2016 r., (Wyrok Sądu Najwyższego z dnia 9 sierpnia 2016 r. .II CSK 719/15, OSNC 2017/5/60, Biul.SN 2016/10/10) stwierdzono tam, że doprowadzenie czynem niedozwolonym do ciężkiego uszczerbku na zdrowiu dziecka, którego efektem jest niemożność nawiązania z nim typowej więzi rodzinnej, stanowi naruszenie dóbr osobistych matki (rodziców). Z aksjologicznego punktu widzenia, brak podstaw do czynienia dyferencjacji między zerwaniem więzi rodzinnej wskutek śmierci, a niemożnością jej nawiązania $z$ uwagi na poważny uszczerbek na zdrowiu, w każdym z tych przypadków dochodzi bowiem do naruszenia dobra osobistego, choć $\mathrm{z}$ różną intensywnością.

Zupełnie odmienne rozstrzygnięcie zapadło $w$ sprawie rozpatrywanej przez Sąd Najwyższy ${ }^{13}$ (Postanowienie Sądu Najwyższego z dnia 21 kwietnia 2017 r.,

${ }^{13}$ Warto zarysować stan faktyczny tej sprawy i główne tezy uzasadnienia tego orzeczenia. „W chwili urodzenia stan dziecka był krańcowo ciężki, małoletnia powódka w skali Apgar uzyskała 0 - 3 pkt Doznała uszkodzenia mózgu w następstwie czego cierpi na małogłowie, czterokończynową postać mózgowego porażenia dziecięcego $\mathrm{z}$ bardzo znacznym upośledzeniem rozwoju umysłowego, ma lekoodporną padaczkę, nie mówi, nie siedzi, nie przekręca się na boki, nie kontroluje czynności fizjologicznych, cierpi na refluks żołądkowo - przełykowy, ma zez zbieżny, nie je samodzielnie, nie 
I CSK 472/16, LEX $n r$ 2305912). W uzasadnieniu tego orzeczenia stwierdzono, że art. $446 \$ 4$ k.c. wskazuje, że ustawodawca udzielił ochrony temu dobru osobistemu, o którym mowa, tylko w razie zerwania więzi przez śmierć.

Zdaniem Sądu Najwyższego przeciwko przyznaniu zadośćuczynienia rodzicom chorego dziecka przemawia brzmienie art. $446 \$ 4$ k.c. a także i to, że co prawda życie członków rodziny poszkodowanego, który doznał poważnego uszczerbku na zdrowiu, ulega pogorszeniu to jednak ich więź z poszkodowanym zostaje zachowana. Członkowie rodziny poszkodowanego nie tracą tym samym dobra osobistego jakim jest więź rodzinna, staje się ona jedynie więzią niewątpliwie innego rodzaju, wyrażana jest w inny sposób. Nie można jednak twierdzić, że jest to więź gorsza. Jej odmienność polega na konieczności dostosowania oczekiwań do stanu zdrowia poszkodowanego. Jednakże to, że są to oczekiwania inne niż były w odniesieniu, jak w sprawie niniejszej, do dziecka zdrowego, nie powinno podlegać rekompensacie. Stan zadowolenia z życia rodzinnego nie jest prawnie gwarantowany. Opierając się na wskazanych argumentach Sąd Najwyższy stwierdził, że należy przyjąć, że brak jest podstawy prawnej dla zasądzenia zadośćuczynienia pieniężnego za krzywdę polegającej na cierpieniach psychicznych, którą ponosi członek rodziny w przypadku uszkodzenia ciała lub rozstroju zdrowia osoby najbliższej; powyższe wymagałoby interwencji ustawodawcy.

\section{Wzajemna relacja pojęć "krzywdy”, ,szkody niemajątkowej” i "cierpień psychicznych"}

Na gruncie obowiązujących przepisów prawa polskiego a w szczególności mając na uwadze treść art. art. $446 \$ 4$ k.c. wyodrębnianie pojęcia krzywdy od pojęcia szkody niemajątkowej nie jest zasadne. Zadośćuczynienie jest przyznawane jedynie w ściśle określonych przez prawo przypadkach, które ustawodawca określa mianem krzywdy. Pojęcie „szkody niemajątkowej” ma niewątpliwie znacznie szerszy zakres znaczeniowy. Roszczeniami odszkodowawczymi nie jest przecież jak wiadomo obecnie objęte tzw. pretium affectionis. Szkoda niemajątkowa przejawia się w postaci odczuwanego przez poszkodowanego bólu i cierpienia, stresu, dyskomfortu, świadomości konieczności życia z nieuleczalnym urazem lub innych ujemnych przeżyć psychicznych. W orzecznictwie stwierdzono, ze wyrządzenie szkody niemajątkowej uprawnia sąd do przyznania zadośćuczynienia tylko wtedy, gdy ze względu na rodzaj, przebieg i skutki doznanego uszkodzenia lub rozstroju zdrowia krzywda poszkodowanego jest

żuje pokarmu, ma zaburzenia połykania, wydaje nieartykułowane dźwięki sygnalizujące stan emocjonalny - zadowolenie, dyskomfort, rozdrażnienie, wymaga stałej opieki; jej stan nie rokuje poprawy. 
realna i istotna. Dolegliwości psychiczne mogą wystąpić więc w przypadkach w których brakuje naruszenia dóbr osobistych (krzywdy w rozumieniu K.C.) jednak pamiętać należy, że cierpienia psychiczne mimo, że nie zawsze będą podstawą zadośćuczynienia to gdy są odpowiednio intensywne kwalifikowane będą mogły być jako rozstrój zdrowia (dobro osobiste wymienione w art. $445 \$ 1 \mathrm{kc}$ ).

Pojęcie cierpień psychicznych w literaturze opisywane jest jako „ujemne uczucia przeżywane w związku z cierpieniami fizycznymi lub następstwami uszkodzenia ciała lub rozstroju zdrowia, które bezpośrednio związane są ze stanem zdrowia oraz dalszymi następstwami w postaci chociażby odczuwalnego dyskomfortu w wygodzie, mobilności, zeszpecenia, niemożliwości wykonywania określonych aktywności życiowych, poczuciu nieprzydatności społecznej, czy nawet wykluczenia"14. Pojęcie cierpień psychicznych jak się wydaje zawiera się w szerszym pojęciu którym jest krzywda moralna.

W prawie europejskim podjęto wspólną próbę opracowania projektu Zasad Europejskiego Prawa Czynów Niedozwolonych ${ }^{15}$. Z treści art. 10:301 Europejskiego Prawa Czynów Niedozwolonych wynika, że za „naruszenie dobra może uzasadniać przyznanie zadośćuczynienia. Zadośćuczynienia można żądać $w$ szczególności w razie szkody na osobie, naruszenia godności, wolności lub innych dóbr osobistych. Roszczenie o zadośćuczynienie może również przysługiwać osobom, które pozostaja w bliskim związku z poszkodowanym, który ponióst śmierć lub doznat innego bardzo poważnego uszczerbku". (2) Co do zasady, wysokość zadośćuczynienia powinna uwzględniać wszystkie okoliczności sprawy, w tym rozmiar, trwałość $i$ skutki krzywdy. Stopień winy sprawcy może wplywać na wysokość odszkodowania jedynie, gdy zawinienie przyczyniło sie znacznie do krzywdy poszkodowanego. (3) W razie szkody na osobie, krzywda odpowiada rozmiarowi cierpienia osoby poszkodowanej i zaburzeń jej zdrowia fizycznego i psychicznego. Przy ustalaniu wysokości zadośćczynienia (włącznie zodszkodowaniem przysługującym osobom pozostającym w bliskim stosunku ze zmartym lub ciężko poszkodowanym) podobne sumy powinny być zasądzane za obiektywnie podobne szkody."'16

$\mathrm{W}$ obecnym stanie, na gruncie prawa polskiego prawnym nie wszystkie sytuacje, które wywołują krzywdę moralną (tzw. dyskomfort psychiczny czy

${ }^{14}$ Por. (Kodeks cywilny. Komentarz LEX. Tom III Zobowiązania. Część ogólna. 2 wydanie., A. Kidyba (red. nauk.), Warszawa 2014, s. 565; podobnie Kodeks cywilny. Komentarz. Zobowiazania, III cz. 1, J. Gudowski (red.), Warszawa 2013, s. 754.

${ }^{15}$ European Group on Tort Law. (2005). Zasady europejskiego prawa czynów niedozwolonych (Principles of European Tort Law PETL). http://civil.udg.es/tort/principles/text_PL.htm

${ }^{16}$ Szerzej na ten temat por. E. Bagińska, Modele regulacji zadośćuczynienia za śmierć osoby bliskiej w wybranych krajach UE. Zadośćuczynienie po nowelizacji Kodeksu Cywilnego na tle doświadczeń europejskich - materiały konferencyjne. Warszawa 2009; A. Szpunar, A. Wynagrodzenie szkody wynikłej wskutek śmierci osoby bliskiej. Bydgoszcz 2000, s. 8 i n. 
wręcz cierpienia psychiczne człowieka) objęte są ochroną prawną za pomocą konstrukcji ochrony dóbr osobistych prawa cywilnego. Obrazowo ujął to Sąd Okręgowy w Gdańsku, który w jednym z uzasadnień słusznie stwierdził, że: „miłość do rodziców czy przywiązanie do zwierząt domowych mieszczą się we wskazanej formule wartości uznanych w społeczeństwie, nie są dobrami osobistymi. Do naruszenia któregoś z wymienionych lub uznanych w judykaturze dóbr nie da się sprowadzić również naruszenia spokoju psychicznego człowieka i jego uczuć, czy też tak jak w tym przypadku wywołania określonego negatywnego stosunku emocjonalnego do zdarzenia czy rzeczy".

W orzecznictwie Sądu Najwyższego pojawiło się jednak krytycznie ocenione przez doktrynę prawa orzeczenie z dnia 17 marca 1988 r., gdzie za dobro osobiste uznano „spokój psychiczny”. Jako przykład dobra osobistego, którego główną osią jest troska o pewien komfort psychiczny w określonej sferze ludzkiego życia podać można dobro osobiste w postaci nietykalności mieszkania. Jako przykład rozumienia tego dobra wskazać można tu sprawę rozpatrywaną przez Sąd Najwyższy a dotyczącą naruszenie dóbr osobistych powodów przez zlokalizowanie w ich sąsiedztwie ich mieszkania zakładu świadczącego usługi pogrzebowe ${ }^{17}$. W sprawie tej Sąd Najwyższy dopatrzył się w tym fakcie naruszenia dwóch dóbr osobistych nietykalności mieszkania oraz zdrowia.

Wiele jest przykładów z orzecznictwa, które potwierdzają tezę, że mimo tego że powód doznał jakichś nieprzyjemności lub czół dyskomfort psychiczny związany z pewną sytuacją nie stwierdzono naruszenia jakiegokolwiek dobra osobistego. W orzecznictwie wielokrotnie powtarzano stwierdzenie, że nie każda, bowiem niedogodność, dyskomfort wywołany czyimś zachowaniem czy nawet krzywda oznacza, że naruszone zostało podlegające ochronie dobro osobiste.

Dla przykładu w judykaturze przeważa pogląd, że nie każdą więź rodzinną automatycznie należy zaliczyć do katalogu dóbr osobistych, na szczególną ochronę prawną zasługuje jedynie taka więź, której zerwanie powoduje ból, cierpienie i rodzi poczucie krzywdy ${ }^{18}$.

W orzecznictwie jako ugruntowany pogląd przyjmuje się, że wywołanie znaczącego dyskomfortu psychicznego (wstrząsu psychicznego) może prowadzić do rozstroju zdrowia osoby fizycznej. Przez pojęcie rozstroju zdrowia rozumie się „wywołanie dysfunkcji organizmu człowieka przez doprowadzenie do zakłócenia funkcjonowania jego poszczególnych układów i systemów (np.

17 Wyrok SN z dnia 11 października 2007 r., IV CSK 264/07, OSNC-ZD 2008, nr 3, poz. 82

18 Wyrok Sądu Apelacyjnego w Gdańsku z dnia 26 kwietnia 2013 r., V ACa 189/13, LEX nr 1362686; por. J. Jastrzębski, Kilka uwag o naprawieniu szkody niemajątkowej, Palestra 2005, z. 3-4, s. 46 i n; A. Szpunar, Uwagi o funkcjach odpowiedzialności odszkodowawczej, PiP 2003, z. 1, s.17 i n.; J. Matys, Wpływ zasad słuszności na zadośćuczynienie pieniężne z tytułu szkody niemajątkowej, w: Wokół zasad prawa cywilnego, (red.) T. Mróz, S. Prutis, Warszawa 2006, s. 46 i n. 
układu pokarmowego, systemu nerwowego. Rozstrój zdrowia urastający do do choroby zwykle uzasadnia własne roszczenie osoby bliskiej ${ }^{19}$.

Dolegliwości psychiczne mogą wystąpić również w przypadkach, w których brakuje naruszenia dóbr osobistych, a przyczyną tych dolegliwości jest np. nadwrażliwość „poszkodowanego”; w takich sytuacjach co do zasady brakuje usprawiedliwienia dla przyznania „poszkodowanemu” zadośćuczynienia pieniężnego. Nie trudno wskazać na wiele sytuacji, które mogą być, źródłem dość intensywnego cierpienia psychicznego i wcale nie będą przejawem nadwrażliwości lecz normalną reakcja każdego przeciętnego, rozsądnie myślącego obywatela. Brak możliwości domagania się w tego rodzaju sytuacjach ochrony prawnej wynikał będzie $\mathrm{z}$ tego powodu, że zdarzenia (okoliczności ), które wywołały ów dyskomfort psychiczny z różnych względów nie zostały zaliczone do katalogu podlegającego szczególnej ochronie i nazywanego mianem „dóbr osobistym”. Na marginesie warto dodać także, że jeśli nawet dojdzie do uznania pewnej wartości za dobro osobiste to nie zawsze $z$ tytułu jego naruszenia przysługiwała będzie pokrzywdzonemu zadośćuczynienie w formie pieniężnej. Tezę tę potwierdził Sąd Apelacyjny w Białymstoku, który stwierdził, że „ciężar gatunkowy poszczególnych dóbr osobistych nie jest jednakowy i nie wszystkie dobra osobiste zasługują na jednakowy poziom ochrony za pomocą środków o charakterze majątkowym".

Obecnie na gruncie prawa austriackiego pokrzywdzony może żądać zadośćuczynienia za uszkodzenie ciała lub wywołanie rozstroju zdrowia ( $\$ 1325$ ABGB), w razie naruszenia integralności seksualnej ( $\$ 1328$ ABGB), oraz przy pozbawieniu wolności ( $\$ 1329$ ABGB). Austriacki Kodeks cywilny pozwala także dochodzić wyrównania uszczerbku niemajątkowego, jeżeli został uszkodzony przedmiot mający dla właściciela szczególną wartość sentymentalną (pretium affectionis - $\$ 1331 \mathrm{ABGB})^{20}$. F. Zoll uważał, że ze względu na brzmienie $₫ 1323$ i $1324 \mathrm{ABGB}$ w prawie cywilnym austriackim wszelka krzywda psychiczna jeżeli została wyrządzona w sposób zawiniony powinna rodzić odpowiedzialność prawną. Prawo austriackie w przeciwieństwie do obowiązującego prawa polskiego daje możliwość dochodzenia roszczeń za każde wyrządzenie szkody niemajątkowej a nie tylko za krzywdę rozumianą wąsko ${ }^{21}$.

19 Por. przykłady z orzecznictwa omówione przez M. Wałachowską, Wynagrodzeni szkód poniesionych na skutek doznania wstrząsu psychicznego spowodowanego śmiercią osoby bliskiej, Przegląd Sądowy 2004, nr 7-8, s. 45 i n.

${ }^{20}$ Z. Radwański, Zadośćuczynienie pieniężne za szkodą niemajątkową. Rozwój i funkcja społeczna, Poznań 1956, s. 49-55.

${ }^{21}$ Por. A. Dembiński, M. Jońca, Leksykon tradycji rzymskiego prawa prywatnego. Podstawowe pojęcia, Warszawa 2016, hasło pretium affectionis, s. 306-307. 


\section{Okoliczności mające wpływ na wysokość zadośćuczynienia} za krzywdę, uwagi na przykładzie spraw dotyczących zadośćuczynienia za śmierć członka rodziny

W odniesieniu do możliwości przyznania zadośćuczynienia za śmierć osoby najbliższej orzecznictwo sądowe jest zgodne co do tego że jest to dopuszczalne zarówno w oparciu o art. $446 \$ 4$ k.c., jak też na podstawie art. 24 k.c. w zw. $\mathrm{z}$ art. $448 \mathrm{k} . \mathrm{c}^{22}$

W polskiej doktrynie prawa w ramach prawa do prywatności dokonano wyodrębnienia szczególnej kategorii dóbr osobistych w postaci „rodzinnych dóbr osobistych" w śród nich wymienia się m. in. dobro osobiste w postaci „więzi rodzinnej”23. W orzecznictwie sądowym nie budzi już obecnie żadnych wątpliwości kwestia, że „Szczególna więź rodziców z dzieckiem, przysługująca zarówno dziecku, jak i rodzicom w prawidłowo funkcjonującej rodzinie, zasługuje na status dobra osobistego, podlegającego ochronie prawnej przewidzianej w art. $24 \$ 1$ k.c." ${ }^{24}$.

Mając na uwadze funkcję kompensacyjną zadośćuczynienia za doznaną krzywdę, jaką jest zerwanie „więzi rodzinnej” ze zmarłym członkiem rodziny głównym celem zasądzanego zadośćuczynienia powinna być chęć zatarcia lub co najmniej złagodzenia następstw naruszenia wskazanego wyżej dobra osobistego. Wysokość zadośćuczynienia powinna zależeć więc przede wszystkim od wielkości doznanej krzywdy. Pomocne mogą być tu dodatkowe kryteria takie

${ }^{22}$ Por. Wyrok Sądu Apelacyjnego w Łodzi z dnia 7 sierpnia 2014 r., I ACa 212/14, LEX nr 1506246; Wyrok Sądu Najwyższego z dnia 16 kwietnia 2014 r., V CSK 320/13, LEX nr 1463645; Wyrok Sądu Apelacyjnego w Łodzi z dnia 7 marca 2014 r., I ACa 1187/13, LEX nr 1454547; Uchwała SN z dnia 22 października 2010 r., III CZP 76/10, LEX nr 604152: por. A. Mączyński, Zadośćuczynienie pieniężne za krzywdę spowodowang naruszeniem dobra osobistego. Geneza, charakterystyka i ocena obowiazującej regulacji w: Odpowiedzialność cywilna. Księga pamiątkowa ku czci Profesora Adama Szpunara, Zakamycze 2004, s. 230 i n.; A. Cisek, W. Dubis (w:) (red.) E. Gniewek, P. Machnikowski, Kodeks cywilny. Komentarz, Warszawa 2016, art. 448, nb 11; M. Safjan (w:) (red.) K. Pietrzykowski, Kodeks cywilny. Komentarz, t. I, 2011, art. 448, nb 25 i n.; por. A. Szpunar, Zadośćuczynienie za szkodę niemajątkowa, Bydgoszcz 1999, s. 208 i n; B. Lewaszkiewicz-Petrykowska, W sprawie wykładni art. 448 k.c., PS 1997, nr 1, s. 6 i n; B. Kordasiewicz, Cywilnoprawna ochrona prawa do prywatności, KPP 2000, z. 1, s. 50; M. Wałachowska, Zadośćuczynienie pieniężne za uszkodzenie ciała lub wywołanie rozstroju zdrowia w prawie polskim, Wiadomości Ubezpieczeniowe 2012, $\mathrm{nr} 2$, s. 10 i n.

23 A. Zielonacki, Wartości życia rodzinnego w świetle ochrony dóbr osobistych (w:) Dobra osobiste $i$ ich ochrona w polskim prawie cywilnym, J. St. Piątowski (red.), Wrocław 1986, s. 231; Z. Radwański, Kodeks cywilny a prawo regulujące zagadnienia rodziny (w:) Problemy wspótczesnego prawa cywilnego (konferencja naukowa), Warszawa 1982, s. 333 i n.

${ }_{24}$ Por Wyrok Sądu Apelacyjnego w Gdańsku z dnia 23 września 2005 r., I ACa 554/05, Palestra 2006, nr 9-10, s. 308; J. Panowicz-Lipska, Majątkowa ochrona dóbr osobistych, Warszawa 1975, s. 68 i n.; M. Pazdan (w:) System prawa prywatnego, t. 1, Prawo cywilne - część ogólna, Z. Radwański (red.), Warszawa 2008, s. 1166 i 1169. P. Bucoń, Zadośćuczynienie Pieniężne z tytułu śmierci najbliższego członka rodziny, Przegląd Prawno-Ekonomiczny 2011, nr 2, s. 16 oraz cytowane tam orzecznictwo. 
jak: rodzaj naruszonego dobra, rozmiar doznanej krzywdy - oceniany obiektywnie, intensywność naruszenia - oceniana obiektywnie, stopień negatywnych konsekwencji dla pokrzywdzonego wynikających z dokonanego naruszenia, nieodwracalność skutków naruszenia, stopień winy sprawcy, oraz sytuacja majątkowa i osobista zobowiązanego oraz sprawcy. Najwyższe zadośćuczynienia powinny być więc zasądzane na rzecz osób, które na skutek śmierci stały się samotne, bez rodziny np. rodziców, którzy utracili ostatnie dziecko i nie będą mogli już mieć własnych dzieci, które były bardzo silnie związane ze swymi członkami rodziny, pozostawały we wspólnym gospodarstwie domowym, aktywnie korzystały ze wsparcia swych bliskich w swej codziennej egzystencji. (por. Wyrok Sądu Apelacyjnego we Wrocławiu z dnia 21 lutego 2013 r., I ACa 60/13, LEX nr 1322898).

W judykaturze zwrócono uwagę, że przy ocenie rozmiaru krzywdy wywołanej naruszeniem dobra osobistego w postaci utraty osoby bliskiej mają wpływ przede wszystkim: wstrząs psychiczny i cierpienia moralne wywołane śmiercią tej osoby, poczucie osamotnienia i pustki po jej śmierci, rodzaj i intensywność więzi łączącej pokrzywdzonego ze zmarłym, rola w rodzinie pełniona przez osobę zmarłą, wystąpienie zaburzeń będących skutkiem śmierci osoby bliskiej, stopień, w jakim pokrzywdzony będzie umiał odnaleźć się w nowej rzeczywistości i zdolność do jej zaakceptowania, wiek pokrzywdzonego. (Por. Wyrok Sądu Apelacyjnego w Poznaniu z dnia 3 lutego 2015 r., I ACa 1274/14, LEX nr 1681966

Postulat racjonalizacji przyznawania ochrony prawnej przemawia za tym chronione prawnie więzi rodzinne przybierały postać rzeczywistych, silnych, trwałych więzi emocjonalnych, których istnienie przejawia się na zewnątrz w taki sposób, iż możliwa jest obiektywna weryfikacja ich istnienia i nie mogą być one utożsamiane jedynie z uczuciem przywiązania do innej osoby. Takie podejście wymaga to od osób dochodzących ochrony szkód niemajątkowych wynikłych z pośrednich naruszeń dóbr osobistych wykazania, że przedmiotem naruszenia była wartość ściśle z nimi związana. (Por. Wyrok Sądu Najwyższego z dnia 9 sierpnia 2016 r. .II CSK 719/15, OSNC 2017/5/60, Biul.SN 2016/10/10).

Jak wskazał Sąd Okręgowy w Sieradzu „zadośćuczynienie należy się członkom najbliższej rodziny zmarłego, a nie każdej osobie bliskiej. Decydujące są zatem przy ocenie w tej mierze nie same więzy pokrewieństwa czy wspólnota gospodarstwa domowego, ale wynikające z okoliczności każdego konkretnego stanu faktycznego więzi osobiste, pewien stosunek bliskości pomiędzy zmarłym a ubiegającym się o to roszczenie, wynikający ze wzajemnych relacji rodzinnych"( Wyrok Sądu Okręgowego w Sieradzu z dnia 27 września 2013 r. I C 85/12, LEX $n$ r 1716678). 


\section{Zakończenie}

Z przeprowadzonych rozważań wynika, że na gruncie obowiązujących przepisów zbędne jest wyodrębnianie pojęć krzywdy i szkody niemajątkowej gdyż tylko to pierwsze $\mathrm{z}$ pojęć pojawia się $\mathrm{w}$ treści regulacji prawnych i uprawnia do domagania się zadośćuczynienia. Pojęcie szkody niemajątkowej ma szerszy zakres znaczeniowy i jego desygnaty nie objęte pojęciem krzywdy nie dają podstaw do domagania się zadośćuczynienia ani odszkodowania. Dokonywanie rozróżnienia na krzywdę i szkodę niemajątkową ma więc jedynie charakter teoretyczny, rozróżnienie to nie ma istotnego znaczenia dla praktyki prawa. Z powyżej przeprowadzonych analiz wynika ponadto, że pojęcie krzywdy nie jest już obecnie związane jedynie $z$ sytuacją osoby, która doznała określonego uszczerbku lecz jest rozumiane szeroko. Krzywda i jej zakres staje się konsekwencją relacji jakie osoba ma lub miała $z$ innymi osobami (np. bliskimi). Uszczerbek, którego doznała tylko jedna osoba może wywoływać więc kilka zasługujących na zadośćuczynienie krzywd osób trzecich związanych emocjonalnie z pokrzywdzonym. Stwierdzenie czy krzywda powstała także u osób trzecich jak się wydaje będzie jedynie konsekwencją intensywności relacji międzyludzkich po między ofiarą a jej bliskimi. Spostrzeżenia te skłaniają do tego aby ustalając wysokość należnego zadośćuczynienia sąd ważył nie tylko uszczerbek w sferze osoby bezpośrednio poszkodowanej ale też odnosząc się do wysokości zadośćuczynienia należnego osobom bliskim poszkodowanego na intensywność i charakter relacji międzyludzkich.

\section{Bibliografia}

Bagińska E., Modele regulacji zadośćuczynienia za śmierć osoby bliskiej w wybranych krajach UE. Zadośćuczynienie po nowelizacji Kodeksu Cywilnego na tle doświadczeń europejskich - materiały konferencyjne. Warszawa 2009.

Bagińska E., Roszczenie o zadośćuczynienie na podstawie art. $446 \S 4$ kodeksu cywilnego na tle doświadczeń europejskich w: Kompensacja szkód komunikacyjnych. Nowoczesne rozwiq̨ania ubezpieczeniowe, red. K. Ludwichowska, Warszawa 2011.

Bucoń P., Zadośćuczynienie Pieniężne z tytułu śmierci najbliższego członka rodziny, Przegląd Prawno-Ekonomiczny 2011, nr 2.

Cisek A., W. Dubis (w:) E. Gniewek (red.), P. Machnikowski (red.), Kodeks cywilny. Komentarz, Warszawa 2016.

Dembiński A., M. Jońca, Leksykon tradycji rzymskiego prawa prywatnego. Podstawowe pojęcia, Warszawa 2016.

European Group on Tort Law. (2005). Zasady europejskiego prawa czynów niedozwolonych (Principles of European Tort Law PETL). http://civil.udg.es/tort/principles/text_PL.htm

Gawlik B., Ochrona dóbr osobistych. Sens i nonsens koncepcji tzw. praw podmiotowych osobistych, ZNUJ PWiOWI 1985, z. 41. 
Grzybowski S., Ochrona dóbr osobistych według przepisów ogólnych prawa cywilnego, Warszawa 1957.

Grzybowski S., Prawa osobistości ze szczególnym uwzględnieniem przepisów prawa cywilnego i administracyjnego o imieniu i nazwisku, Warszawa 1937.

Grzybowski S., Prawo cywilne. Zarys części ogólnej, Warszawa 1985.

Gudowski J. (red.), Kodeks cywilny. Komentarz. Zobowiqzzania, III cz. 1, Warszawa 2013.

Jastrzębski J., Kilka uwag o naprawieniu szkody niemajątkowej, Palestra 2005, z. 3-4.

Kidyba A. (red.), Kodeks cywilny. Komentarz LEX. Tom III Zobowiq̨zania. Część ogólna. 2 wydanie, Warszawa 2014.

Kolańczyk K., Prawo rzymskie, Warszawa 1976.

Kordasiewicz B., Cywilnoprawna ochrona prawa do prywatności, KPP 2000, z. 1.

Lewandowska-Malec I., Dobra osobiste, Warszawa 2014.

Lewaszkiewicz-Petrykowska B., W sprawie wykładni art. 448 k.c., PS 1997, nr 1.

Matys J., Model zadośćuczynienia pieniężnego z tytułu szkody niemajątkowej w kodeksie cywilnym, Warszawa 2012.

Matys J., Wpływ zasad słuszności na zadośćuczynienie pieniężne z tytułu szkody niemajątkowej, w: Wokół zasad prawa cywilnego, (red.) T. Mróz , S. Prutis, Warszawa 2006.

Mączyński A., Zadośćuczynienie pieniężne za krzywdę spowodowana naruszeniem dobra osobistego. Geneza, charakterystyka i ocena obowiq̨zującej regulacji w: Odpowiedzialność cywilna. Księga pamiątkowa ku czci Profesora Adama Szpunara, Zakamycze 2004.

Panowicz-Lipska J., Majątkowa ochrona dóbr osobistych, Warszawa 1975.

Pazdan M. (w:) System prawa prywatnego, t. 1, Prawo cywilne - część ogólna, Z. Radwański (red.), Warszawa 2008.

Radwański Z., Kodeks cywilny a prawo regulujące zagadnienia rodziny (w:) Problemy współczesnego prawa cywilnego (konferencja naukowa), Warszawa 1982.

Radwański Z., Prawo cywilne - część ogólna, Warszawa 1999.

Radwański Z., Zadośćuczynienie pieniężne za szkodą niemajątkowq̨. Rozwój i funkcja społeczna, Poznań 1956.

Safjan M. (w:) K. Pietrzykowski(red.), Kodeks cywilny. Komentarz, t. I, 2011.

Szpunar A., Uwagi o funkcjach odpowiedzialności odszkodowawczej, PiP 2003, z. 1.

Szpunar A., Zadośćuczynienie za szkodę niemajątkowq, Bydgoszcz 1999.

Szpunar, A. . Wynagrodzenie szkody wynikłej wskutek śmierci osoby bliskiej. Bydgoszcz 2000.

Śmieja A., Instytucja zadośćuczynienia pieniężnego za doznaną krzywdę w kodeksie zobowiq̨zań i w kodeksie cywilnym, Acta Universitatis Wratislaviensis 2009.

Wałachowska M., Wynagrodzeni szkód poniesionych na skutek doznania wstrzq̨su psychicznego spowodowanego śmiercią osoby bliskiej, Przegląd Sądowy 2004, nr 7-8.

Wałachowska M., Zadośćuczynienie pieniężne za uszkodzenie ciała lub wywołanie rozstroju zdrowia w prawie polskim, Wiadomości Ubezpieczeniowe 2012, nr 2.

Zielonacki A., Wartości życia rodzinnego w świetle ochrony dóbr osobistych (w:) Dobra osobiste i ich ochrona w polskim prawie cywilnym, J. St. Piątowski (red.), Wrocław 1986.

Wyrok Sądu Apelacyjnego w Gdańsku z dnia 23 września 2005 r., I ACa 554/05, Palestra 2006, nr 9-10. Wyrok SN z dnia 11 października 2007 r., IV CSK 264/07, OSNC-ZD 2008, nr 3, poz. 82.

Uchwała SN z dnia 22 października 2010 r., III CZP 76/10, LEX nr 604152:

Wyrok Sądu Apelacyjnego w Gdańsku z dnia 26 kwietnia 2013 r., V ACa 189/13, LEX nr 1362686.

Wyrok Sądu Apelacyjnego w Łodzi z dnia 7 marca 2014 r., I ACa 1187/13, LEX nr 1454547.

Wyrok Sądu Najwyższego z dnia 16 kwietnia 2014 r., V CSK 320/13, LEX nr 1463645.

Wyrok Sądu Apelacyjnego w Łodzi z dnia 7 sierpnia 2014 r., I ACa 212/14, LEX nr

1506246. 


\section{Streszczenie}

W aktualnie obowiązującym stanie prawnym podstawą roszczeń majątkowych może być m. in. fakt doznania tzw. krzywdy (por. art. 448 kc.). Jak należy interpretować znaczenie tego pojęcia oraz jaka jest jego relacja do takich pojęć jak „szkoda niemajatkowa” czy „cierpienia psychiczne” wciąż jest przedmiotem dyskusji naukowej oraz podlega dynamicznej wykładni sądowej. Kwestią budzącą aktualnie szczególne zainteresowanie jest $\mathrm{m}$. in wpływ doznanej krzywdy poszkodowanego na roszczenia osób trzecich, które z uwagi na ten fakt nie mogą z poszkodowanym utrzymywać właściwych relacji, przykładem takiej sytuacji jest uszczerbek na zdrowiu dziecka (jego trwałe upośledzenie), który może być postrzegany także jako naruszenie dobra osobistego w postaci życia rodzinnego. Celem niniejszego artykułu było więc zrelacjonowanie aktualnie istniejących poglądów dotyczących interpretacji wymienionych powyżej pojęć i zakreślenie podstaw umożliwiających dochodzenie zadośćuczynienia pieniężnego. W artykule przedstawione zostały także okoliczności, które mają pierwszoplanowe znaczenie dla miarkowania wysokości zadośćuczynienia za krzywdę.

Słowa kluczowe: dobra osobiste, krzywda, zadośćuczynienie, szkoda niemajątkowa, cierpienia psychiczne.

\section{Harm suffered and its monetary compensation in civil law. Analysis of concepts in the light of the jurisprudence of Polish courts}

\section{Summary}

In the current legal status, the basis for property claims may be, among others the fact so-called harm suffered. Art 448 Polish Civil Code prescribe that In the event of infringement of one's personal interests the court may award to the person whose interests have been infringed an appropriate amount as monetary recompense for harm suffered (...). How to interpret the meaning of the term "harm suffered". What is the relationship of this term to such terms as , non-pecuniary damage" or "mental suffering"? These issues are currently the subject of scientific discussion and judicial decisions. The purpose of this article was therefore to report the existing views on the interpretation of the above-mentioned concepts and to lay out the grounds for seeking monetary compensation. The article also presents the circumstances that are of prime importance for mending the amount of compensation for harm suffered .

Keywords: personal rights, harm, compensation, non-pecuniary damage, mental suffering. 